\title{
IMPLEMENTASI MODEL PEMBELAJARAN KOOPERATIF TIPE JIGSAW UNTUK MENINGKATKAN PEMAHAMAN AKUNTANSI
}

\section{THE IMPLEMENTATION OF COOPERATIVE LEARNING MODEL TYPE JIGSAW TO INCREASE THE COMPREHENSION OF ACCOUNTING}

\author{
Oleh: \\ Suhartini \\ Pendidikan Akuntansi Universitas Negeri Yogyakarta \\ nini_stt@yahoo.co.id \\ Sukanti, M.Pd. \\ Staf Pengajar Jurusan P. Akuntansi Universitas Negeri Yogyakarta
}

\begin{abstract}
Abstrak
Penelitian ini merupakan Penelitian Tindakan Kelas (Classroom Action Research) yang bertujuan untuk meningkatkan Pemahaman Akuntansi siswa kelas X Akuntansi 2 SMK Negeri 7 Yogyakarta tahun ajaran 2013/2014 melalui Implementasi Model Pembelajaran Kooperatif Tipe Jigsaw. Penelitian ini dilaksanakan dalam bentuk kolaboratif yang dilaksanakan dalam dua siklus. Teknik pengumpulan data dalam penelitian ini melalui observasi, catatan lapangan, dan tes. Teknik analisis data yang digunakan yaitu teknik analisis data deskriptif. Berdasarkan hasil penelitian disimpulkan bahwa Model Pembelajaran Kooperatif Tipe Jigsaw dapat meningkatkan Pemahaman Akuntansi Siswa Kelas X Akuntansi 2 SMK Negeri 7 Yogyakarta Tahun Ajaran 2013/2014. Peningkatan ini diketahui dari hasil observasi yaitu diperoleh skor pemahaman akuntansi secara klasikal pada siklus I sebesar $61,61 \%$ dan pada siklus II sebesar $81,25 \%$. Berdasarkan analisis data diketahui kenaikan siswa yang tuntas KKM dari pre-test ke post-test siklus I adalah sebesar 34,38\%, sedangkan kenaikan siswa yang tuntas KKM dari pre-test ke post-test siklus II adalah sebesar 78,13\%. Selain itu, diketahui terjadi kenaikan dari post-test siklus I ke post-test siklus II sebesar 17,94\%.
\end{abstract}

Kata kunci: Jigsaw, Pemahaman Akuntansi

\begin{abstract}
This research is Classroom Action Research which aims to improve the Accounting Comprehension of class X Akuntansi 2 SMK Negeri 7 Yogyakarta academic year 2013/2014 through the Implementation of Cooperative Learning Model Type Jigsaw. This research was conducted in two cycles of collaborative form. The technique of collecting data in this research was conducted by observation and tests. This research also applied descriptive approach in analyzing the data. Based on the result of the research, it can be concluded that Cooperative Learning Model Type Jigsaw can improve the Accounting Comprehension of class X Akuntansi 2 SMK Negeri 7 Yogyakarta academic year 2013/2014. This increase can be evidence from the result of the observation. In the first cycle, the score of classical comprehension is $61,61 \%$ and it gains $81,25 \%$ in the second cycle which increases $19,64 \%$. Based on the data analysis, it can be known that students who pass the KKM in the pre-test to post-test of the first cycle is $34,38 \%$, while in the second cycle the amount of students who pass the KKM is $78,13 \%$. It proves that the increase from post-test in first cycle to second cycle is $17,94 \%$.
\end{abstract}

Keyword: Jigsaw, Accounting Comprehension 


\section{PENDAHULUAN}

Pendidikan merupakan suatu kebutuhan pokok yang diperlukan bagi setiap manusia dalam memperoleh ilmu dan wawasan. Pendidikan dapat diperoleh baik melalui jenjang formal, informal, maupun non-formal. Sekolah merupakan salah satu tempat pendidikan yang umum digunakan oleh setiap orang. Sekolah sering dijadikan tumpuan utama masyarakat dalam menilai berhasil tidaknya pendidikan. Keberhasilan atau prestasi belajar siswa hanya sering dilihat sebagai kesuksesan dan keunggulan pihak sekolah semata. Sebaliknya, kegagalan atau rendahnya kualitas siswa sering dilihat sebagai ketidakmampuan pihak sekolah menyelenggarakan proses pendidikan.

Keberhasilan proses pembelajaran pada prinsipnya bergantung kepada berbagai faktor yang mempengaruhinya, baik yang datang dari guru, siswa serta dari lingkungan di mana siswa belajar yang masing-masing faktor tersebut memberikan kontribusinya sesuai dengan peranan dan harapan yang ingin dicapai dalam suatu proses pembelajaran. Pendidikan secara menyeluruh mencakup ranah kognitif, afektif dan psikomotorik. Menurut Nana Sudjana (2009: 22-23) ranah kognitif berkenaan dengan hasil belajar intelektual, ranah afektif berkenaan dengan sikap, dan ranah psikomotorik berkenaan dengan hasil belajar keterampilan dan kemampuan bertindak. Guru perlu memahami peran guru dalam pembelajaran untuk memenuhi tuntutan ranah-ranah tersebut. Muhibbin Syah (2010: 84) menyebutkan bahwa "Tugas guru ialah menggunakan pendekatan mengajar yang memungkinkan para siswa menggunakan strategi belajar yang berorientasi pada pemahaman yang mendalam terhadap isi materi pelajaran".

\begin{tabular}{lccr}
\multicolumn{1}{c}{ Banyak } & faktor yang & dapat \\
mempengaruhi & prestasi belajar & siswa \\
khususnya & aspek & kognitif & yaitu \\
pemahaman & siswa dalam & proses
\end{tabular}
pembelajaran. Faktor tersebut antara lain adalah tujuan pembelajaran, siswa, guru, dan kegiatan pembelajaran yang terkait dengan model dan media pembelajaran. Model pembelajaran yang diterapkan guru merupakan salah satu faktor yang mempengaruhi pemahaman siswa. Guru perlu mengembangkan model-model pembelajaran modern yang lebih sesuai dengan sifat manusiawi siswa dengan kondisi siswa, guru, dan sekolah, serta lebih memperhatikan kondisi kejiwaan siswa dalam melakukan proses belajar. Menurut Isjoni (2008: 146) "Model pembelajaran merupakan strategi yang digunakan guru untuk meningkatkan motivasi belajar, sikap belajar di kalangan siswa, mampu berpikir kritis, memiliki keterampilan sosial, dan pencapaian hasil pembelajaran yang lebih optimal”.

Pelaksanaan pembelajaran akuntansi di Kelas X Akuntansi 2 SMK Negeri 7 Yogyakarta belum berlangsung secara optimal. Berdasarkan hasil observasi yang dilaksanakan tanggal 27 Agustus 2013 ketika guru menggunakan metode ceramah dan latihan soal untuk menyampaikan materi, hanya beberapa siswa saja (10 dari 32 siswa) atau sebesar $31,25 \%$ siswa yang paham akan materi yang diajarkan. Hal itu dilihat dari hanya beberapa siswa yang mampu menanggapi dan menginterpretasikan materi yang telah disampaikan oleh guru. Berdasarkan hasil observasi yang dilakukan peneliti di kelas $\mathrm{X}$ Akuntansi 2, masih terdapat 10 orang siswa dari 32 siswa atau sekitar $31,25 \%$ siswa yang nilainya masih di bawah Kriteria Ketuntasan Minimal. Tingkat pemahaman akuntansi siswa ini diketahui berdasarkan hasil tes yang dilaksanakan tanggal 6 September 2013. Data ini diambil dari nilai ulangan siswa pada Standar Kompetensi Mengelola Dokumen Transaksi. Hasil observasi lebih diperkuat dengan keterangan guru yang menyatakan bahwa tingkat pemahaman akuntansi siswa masih rendah. Berdasarkan hasil wawancara dengan beberapa siswa diketahui bahwa penyebab rendahnya pemahaman akuntansi siswa adalah 
metode mengajar guru. Guru pengampu juga mengutarakan sudah banyak mengikuti seminar tentang berbagai macam metode dan model pembelajaran tetapi guru tersebut belum mampu memahami dan menerapkannya dengan baik di kelas. Oleh karena itu hal ini perlu dicari pemecahannya. Proses belajar mengajar perlu diperbaiki dan pemahaman akuntansi siswa perlu ditingkatkan agar hasil belajar siswa juga meningkat. Salah satu upaya untuk meningkatkan pemahaman akuntansi siswa adalah dengan memperbaiki model mengajar guru. Guru harus dapat menyesuaikan bahan ajar dengan model atau strategi pembelajaran yang tepat agar pemahaman akuntansi siswa meningkat.

Model pembelajaran yang dapat digunakan untuk meningkatkan pemahaman akuntansi siswa salah satunya adalah Model Pembelajaran Kooperatif Tipe Jigsaw. Menurut Agus Suprijono (2012: 54-55) model pembelajaran kooperatif melibatkan interaksi diantara siswa di mana dalam proses pembelajaran senantiasa didasarkan atas kerja sama tim, masing-masing individu mempunyai tanggung jawab dalam mencapai tujuan kelompok. Penerapan model pembelajaran kooperatif dalam kegiatan pembelajaran diharapkan dapat meningkatkan pemahaman akuntansi siswa sehingga kegiatan pembelajaran dapat menjadi lebih bermakna.

"Jigsaw adalah salah satu tipe dari metode-metode kooperatif yang paling fleksibel" (Slavin, 2005: 246). Jigsaw bisa digunakan dalam pengajaran membaca, menulis, mendengarkan, ataupun berbicara. Pembelajaran dengan metode Jigsaw dapat dibentuk menjadi 2 kelompok, yaitu kelompok asal dan kelompok ahli. "Jigsaw cocok untuk semua mata pelajaran" (Anita Lie, 2008: 69). Menurut Miftahul Huda (2012: 149) manfaat metode Jigsaw adalah pemahaman siswa dapat meningkat karena siswa berdiskusi pada kelompok ahli dengan siswa lain yang memiliki tanggung jawab yang sama, selain itu siswa juga berdiskusi pada kelompok asal sehingga memperoleh pengetahuan yang menyeluruh mengenai materi yang dipelajari.

Merefleksi fenomena di atas peneliti menetapkan untuk menerapkan Model Pembelajaran Kooperatif Tipe Jigsaw pada kegiatan pembelajaran di kelas $\mathrm{X}$ Akuntansi 2 SMK Negeri 7 Yogyakarta pada Kompetensi Dasar Membuat Jurnal Penyesuaian dalam bentuk penelitian tindakan kelas. Sifat belajar dalam pembelajaran kooperatif tidak sama dengan belajar kelompok atau belajar bekerja sama biasa. Dalam kerja kelompok, guru biasanya membagi kelompok lalu memberikan tugas kelompok tanpa rancangan tertentu. Akibatnya, siswa ada yang bekerja aktif tetapi ada juga yang pasif, ataupun bahkan ada yang bermain-main atau berbicara dengan temannya. Dalam pembelajaran kooperatif, setiap siswa dituntut untuk bekerja dalam kelompok melalui rancangan-rancangan tertentu yang sudah dipersiapkan oleh guru sehingga seluruh siswa harus bekerja aktif. Slavin (1995) dalam Rusman (2011: 205) menyebutkan bahwa "Penggunaan pembelajaran kooperatif dapat meningkatkan prestasi belajar siswa dan sekaligus dapat meningkatkan hubungan sosial, menumbuhkan sikap toleransi, dan menghargai pendapat orang lain". Para guru pada umumnya menggunakan model yang berbasis persaingan di dalam kelas, hal ini berdampak negatif bagi para siswa. Pada kenyataannya jika diatur dengan baik, persaingan diantara siswa tersebut dapat menjadi sarana yang efektif dan memotivasi siswa melakukan yang terbaik. Langkah tersebut diambil karena dengan menggunakan model pembelajaran kooperatif, siswa akan termotivasi untuk dapat mengungkapkan ide di dalam wadah kelompok. Mereka memiliki tempat untuk mencurahkan pendapat dengan teman, selain itu tujuan pembelajaran kooperatif 
adalah menciptakan sebuah situasi di mana satu-satunya cara anggota kelompok bisa meraih tujuan pribadi mereka. Jika dalam kelompok mereka bisa sukses, hal itu dapat mendorong mereka untuk melakukan usaha maksimal. Pada akhirnya, dengan menerapkan Model Pembelajaran Kooperatif Tipe Jigsaw di dalam proses pembelajaran diharapkan pemahaman akuntansi siswa terhadap materi yang diajarkan dapat meningkat.

Sesuai dengan analisis situasi yang telah disebutkan, peneliti bermaksud melakukan penelitian tindakan kelas dengan judul "Implementasi Model Pembelajaran Kooperatif Tipe Jigsaw untuk Meningkatkan Pemahaman Akuntansi Siswa Kelas X Akuntansi 2 SMK Negeri 7 Yogyakarta Tahun Ajaran 2013/2014".

\section{METODE PENELITIAN \\ Desain Penelitian}

Jenis penelitian ini adalah Penelitian

Tindakan Kelas (Classroom Action Research). Rochiati Wiriaatmadja (2006: 13) menyebutkan "Penelitian tindakan kelas adalah bagaimana sekelompok guru dapat mengorganisasikan kondisi praktik pembelajaran mereka, dan belajar dari pengalaman mereka sendiri". Prosedur yang digunakan adalah proses penelitian tindakan model Kemmis dan Taggart, dengan melakukan 2 siklus. Penelitian ini dilaksanakan melalui bentuk kolaboratif antara peneliti dan guru pelajaran Akuntansi.

\section{Waktu dan Tempat Penelitian}

Penelitian dilakukan di Kelas $\mathrm{X}$ Akuntansi 2 SMK Negeri 7 Yogyakarta yang beralamat di Jalan Gowongan Kidul JT. III/ 416 Yogyakarta. Penelitian dilakukan meliputi tahap persiapan pada bulan September 2013. Tahap pelaksanaan sampai tahap pelaporan yaitu pada bulan Oktober hingga Desember 2013.

\section{Subjek dan Objek Penelitian}

Subjek penelitian ini adalah seluruh siswa kelas X Akuntansi 2 SMK Negeri 7 Yogyakarta tahun ajaran 2013/2014 yang berjumlah 32 siswa, sedangkan objek penelitian ini adalah Implementasi Model Pembelajaran Kooperatif Tipe Jigsaw sebagai upaya untuk meningkatkan Pemahaman Akuntansi Siswa Kelas X Akuntansi 2 SMK Negeri 7 Yogyakarta Tahun Ajaran 2013/2014.

\section{Prosedur Penelitian}

Penelitian ini akan dilakukan secara kolaboratif dengan guru mata pelajaran akuntansi kelas $\mathrm{X}$ Akuntansi 2 SMK Negeri 7 Yogyakarta. Penelitian ini akan dilaksanakan sebanyak dua siklus, dimana masing-masing siklus terdiri dari beberapa komponen, yaitu perencanaan, pelaksanaan, pengamatan dan refleksi. Adapun prosedur pelaksanaannya adalah sebagai berikut:

\section{Siklus I}

a. Tahap Perencanaan tindakan

1) Menyusun Rencana Pelaksanaan Pembelajaran (RPP) tentang materi Membuat Jurnal Penyesuaian sesuai dengan Model Pembelajaran Kooperatif Tipe Jigsaw.

2) Merancang materi pembelajaran tentang Membuat Jurnal Penyesuaian.

3) Menyusun Student Worksheet yang mencakup materi Membuat Jurnal Penyesuaian, catatan lapangan, dan lembar observasi.

4) Menyusun soal pre-test dan posttest siklus I dan siklus II tentang jurnal penyesuaian, dan soal yang digunakan sebagai latihan dan tugas pekerjaan rumah siswa.

b. Tahap Pelaksanaan Tindakan

Apabila tahap perencanaan tindakan telah matang, maka langkah selanjutnya yaitu melaksanakan rencana tersebut di kelas dengan berpedoman pada Rencana 
Pelaksanaan Pembelajaran yang telah disusun sebelumnya. Pada tahap ini guru sebagai tenaga pengajar melaksanakan tindakan berdasarkan RPP yang telah disusun, sedangkan peneliti melakukan penelitian terhadap segala kegiatan yang dilakukan siswa selama proses pembelajaran dengan menggunakan Model Pembelajaran Kooperatif Tipe Jigsaw. Pelaksanaan ini bersifat fleksibel atau berubah-ubah sesuai dengan situasi dan kondisi yang terjadi di lapangan.

c. Tahap Pengamatan/Observasi

Tahap pengamatan/observasi dilakukan saat pembelajaran berlangsung, sehingga tahap ini berjalan bersamaan dengan saat pelaksanaan. Kegiatan yang dilakukan pada tahap ini adalah melakukan pengamatan dan mencatat semua hal yang terjadi selama pelaksanaan tindakan berlangsung seperti kegiatan pengkondisian kelas oleh guru, kegiatan siswa saat mengerjakan pre-test dan post-test, pembagian kelompok, kegiatan diskusi siswa, presentasi siswa, pembahasan materi, dan pembuatan kesimpulan secara bersama-sama oleh siswa dan guru.

d. Tahap Refleksi

Tahap refleksi dimaksudkan untuk mengkaji secara menyeluruh tindakan yang telah dilakukan berdasarkan data yang telah terkumpul, kemudian dilakukan evaluasi guna menyempurnakan tindakan berikutnya. Refleksi dilakukan dengan diskusi bersama guru mata pelajaran Akuntansi berdasarkan hasil dari tindakan siklus pertama. Berdasarkan hasil refleksi dari proses pembelajaran yang dilaksanakan pada siklus pertama, peneliti bersama dengan guru menyusun rencana pemecahan masalah untuk memperbaiki proses pembelajaran pada siklus kedua.

\section{Siklus II}

a. Tahap Perencanaan Tindakan Pada tahap ini kegiatannya hampir sama dengan siklus I, tetapi perencanaan pada siklus II merupakan perbaikan terhadap kekurangan yang terjadi pada siklus I berdasarkan refleksi yang telah dilakukan. Pada tahap perencanaan siklus II, selain menyusun Rencana Pelaksanaan Pembelajaran (RPP) dan merancang materi pembelajaran, peneliti juga menyusun soal pre-test dan post-test siklus II tentang jurnal penyesuaian, dan soal yang digunakan sebagai latihan dan tugas pekerjaan rumah siswa tentang jurnal penyesuaian.

b. Tahap Pelaksanaan Tindakan

Sama halnya dengan siklus I, apabila tahap perencanaan tindakan telah matang, maka langkah selanjutnya yaitu melaksanakan rencana tersebut di kelas dengan berpedoman pada Rencana Pelaksanaan Pembelajaran yang telah disusun sebelumnya. Pada tahap pelaksanaan ini bersifat fleksibel atau berubah-ubah, dapat dimodifikasi sewaktu-waktu sesuai dengan situasi dan kondisi serta keperluan yang terjadi di lapangan. Mengenai segala perubahan akan dicatat dalam catatan lapangan.

c. Tahap Pengamatan/Observasi

Tahap pengamatan/observasi dilakukan saat pembelajaran berlangsung, sehingga tahap ini berjalan bersamaan dengan saat pelaksanaan. Kegiatan yang dilakukan pada tahap ini adalah melakukan pengamatan dan mencatat semua hal yang terjadi selama pelaksanaan tindakan berlangsung 
seperti kegiatan pengkondisian kelas oleh guru, kegiatan siswa saat mengerjakan pre-test dan post-test, pembagian kelompok, kegiatan diskusi siswa, presentasi siswa, pembahasan materi, dan pembuatan kesimpulan secara bersama-sama oleh siswa dan guru.

d. Tahap Refleksi

Tahap refleksi dimaksudkan untuk mengkaji secara menyeluruh tindakan yang telah dilakukan berdasarkan data yang telah terkumpul baik dari siklus I maupun siklus II. Refleksi dilakukan dengan diskusi bersama guru mata pelajaran Akuntansi berdasarkan hasil dari tindakan siklus kedua. Jika terdapat masalah dari proses refleksi, maka dilakukan proses pengkajian ulang melalui siklus berikutnya sehingga permasalahan dalam siklus I dan II dapat terselesaikan.

\section{Teknik Pengumpulan Data}

\section{Observasi}

"Dalam penelitian tindakan kelas, observasi dipusatkan baik kepada proses maupun hasil tindakan pembelajaran beserta segala peristiwa yang melingkupinya" (Wijayah Kusuma dan Dedi Dwitagama, 2011: 70). Observasi atau pengamatan adalah teknik yang digunakan untuk mengumpulkan data mengenai proses dan hasil belajar peserta didik dengan menggunakan Model Pembelajaran Kooperatif Tipe Jigsaw berkaitan dengan peningkatan pemahaman akuntansi siswa.

2. Tes

"Tes merupakan instrumen untuk mengumpulkan data prestasi belajar peserta didik, baik melalui tes lisan, tertulis, maupun perbuatan" (Mulyasa, 2009: 69). Tes tertulis yang digunakan peneliti dimaksudkan untuk mengetahui tingkat pemahaman dan penguasaan siswa terhadap materi jurnal penyesuaian yang diajarkan dengan
Model Pembelajaran Kooperatif Tipe Jigsaw.

\section{Instrumen Penelitian}

\section{Pedoman Observasi}

Agar observasi dapat berhasil dengan baik, diperlukan alat berupa pedoman observasi. "Pedoman observasi digunakan untuk menjaring data dalam proses belajar mengajar. Peneliti akan lebih mudah mengamati aktivitas guru dan siswa bila sudah disiapkan pedoman observasinya (Zainal Aqib, dkk, 2008: 157). Pedoman obervasi merupakan merupakan pedoman bagi observer untuk mengamati hal-hal yang akan diamati. Dalam penelitian ini, pedoman observasi diisi dengan cara memberikan alternatif skor yaitu 0,1 dan 2. Kegiatan ini mengacu pada indikator Pemahaman Akuntansi Siswa.

\section{Catatan Lapangan}

Menurut Rochiati Wiriaatmaja (2006: 125) "Sumber informasi yang sangat penting dalam penelitian tindakan kelas adalah catatan lapangan yang dibuat oleh peneliti yang melakukan pengamatan atau observasi". Catatan lapangan digunakan untuk menuliskan tentang segala hal yang terjadi dalam pembelajaran di kelas yang berkaitan dengan penerapan Model Pembelajaran Kooperatif Tipe Jigsaw seperti kondisi kelas, perilaku siswa saat mengerjakan pre-test dan post-test, saat diskusi kelompok, saat presentasi hasil diskusi, dan pembahasan materi jurnal penyesuaian serta kegiatan guru seperti membuka pelajaran, membagi kelompok, membimbing diskusi siswa, dan memberikan konfirmasi.

3. Tes

Tes dilakukan untuk mengukur sejauh mana tingkat pemahaman akuntansi tentang materi pembelajaran yang disampaikan oleh guru. Tes yang digunakan dalam penelitian ini adalah 
bentuk tes tertulis berupa tes pilihan ganda dan tes essay atau uraian. "Bentuk soal pilihan ganda merupakan bentuk soal yang jawabannya harus memilih beberapa kemungkinan jawaban yang telah disediakan dalam soal (Moh. Sholeh Hamid: 2011: 197). Sedangkan "Tes uraian merupakan tes yang menuntut peserta didik untuk menguraikan, mengorganisasikan dan menyatakan jawaban dengan katakatanya sendiri dalam bentuk, teknik, dan gaya yang berbeda satu dengan lainnya" (Zainal Arifin, 2012: 125). Tes dalam penelitian ini dilakukan disetiap awal (pre-test) dan akhir pembelajaran (post-test).

4. Lembar Kerja Siswa

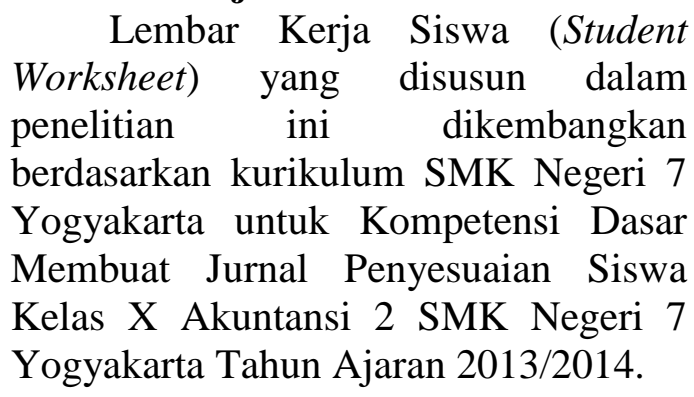

\section{Teknik Analisis Data}

Teknik analisis data yang digunakan dalam penelitian ini adalah teknik analisis data deskriptif. Data yang diperoleh dari hasil observasi dianalisis untuk mengetahui persentase skor pemahaman akuntansi sebagai berikut (Sugiyono, 2009: 144):

a. Menentukan kriteria pemberian skor terhadap masing-masing indikator pemahaman akuntansi yang diamati.

b. Menjumlahkan skor untuk masingmasing indikator pemahaman akuntansi yang diamati.

c. Menghitung skor pemahaman akuntansi pada setiap indikator yang diamati dengan rumus:

$$
\%=\frac{\text { Skor Pemahaman Akuntansi }}{\text { Skor Maksimum }} \times 100 \%
$$

Teknik analisis data kuantitatif digunakan untuk menghitung peningkatan pemahaman akuntansi siswa secara klasikal dengan menggunakan rumus:

$M e=\frac{\sum x i}{N}$

Keterangan :

$\mathrm{Me} \quad$ : Rata-rata (mean)

$\sum x i \quad$ Jumlah semua nilai

$N$ : Jumlah individu

(Sugiyono, 2010: 49)

\section{Indikator Keberhasilan}

Indikator keberhasilan dalam penelitian ini adalah Model Pembelajaran Kooperatif Tipe Jigsaw dapat diimplementasikan dengan baik sesuai dengan perencanaan yang telah dibuat. Pembelajaran dikatakan berhasil dan berkualitas jika seluruhnya atau sebagian besar $(75 \%)$ siswa terlibat secara aktif baik fisik maupun mental (Mulyasa, 2010: 218). Keberhasilan tindakan dalam proses pembelajaran dapat dilihat baik dari skor tiap indikator Pemahaman Akuntansi maupun secara keseluruhan dalam satu kelas sekurang-kurangnya memperoleh persentase $75 \%$. Selain itu terjadi peningkatan skor indikator Pemahaman Akuntansi pada kompetensi dasar membuat jurnal penyesuaian. Keberhasilan tindakan juga dapat dilihat apabila $75 \%$ siswa dalam satu kelas mencapai nilai KKM yaitu 75 .

\section{HASIL PENELITIAN DAN PEMBAHASAN}

Hasil penelitian diperoleh baik dari siklus I maupun siklus II. Hasil penelitian siklus I adalah semua indikator yang ditentukan belum ada yang mencapai kriteria keberhasilan yaitu $75 \%$ dan hanya 11 siswa dari 32 siswa atau 34,38\% yang telah mencapai nilai KKM. Berdasarkan hasil tersebut, maka pada siklus II perlu dilakukan perbaikan agar pemahaman akuntansi siswa kelas X Akuntansi 2 dapat mencapai kriteria yang telah ditentukan. Salah satu cara untuk mengatasi masalah 
tersebut adalah dengan pengarahan, bimbingan, dan pengawasan yang lebih intensif dari guru. Terbukti bahwa terjadi peningkatan pemahaman akuntansi sebesar $19,64 \%$ dari siklus I ke siklus II dan semua indikator telah mencapai kriteria keberhasilan tindakan. Jumlah siswa yang mencapai KKM pun meningkat dari 11 siswa $(34,38 \%)$ pada siklus I menjadi 28 siswa $(87,50 \%)$ pada siklus II. Untuk lebih jelasnya, berikut ini disajikan data perbandingan skor Pemahaman Akuntansi siswa kelas X Akuntansi 2 siklus I dan siklus II:

Tabel 1. Perbandingan Persentase Pemahaman Akuntansi

\begin{tabular}{|l|c|c|c|}
\hline \multirow{2}{*}{ Indikator } & \multicolumn{2}{|c|}{ Persentase } & $\begin{array}{c}\text { Pening- } \\
\text { katan } \\
\text { (\%) }\end{array}$ \\
\cline { 2 - 4 } & $\begin{array}{c}\text { Siklus } \\
\text { I }\end{array}$ & $\begin{array}{c}\text { Siklus } \\
\text { II }\end{array}$ & II-I \\
\hline $\begin{array}{l}\text { Memberikan } \\
\text { interpretasi }\end{array}$ & 58,87 & 76,56 & 17,69 \\
\hline $\begin{array}{l}\text { Memberikan } \\
\text { ide-ide dan } \\
\text { pendapat }\end{array}$ & 54,03 & 80,47 & 26,44 \\
\hline $\begin{array}{l}\text { Memberikan } \\
\text { contoh nyata } \\
\text { dari suatu } \\
\text { konsep }\end{array}$ & 58,06 & 76,56 & 18,5 \\
\hline $\begin{array}{l}\text { Mengerjakan } \\
\text { soal dengan } \\
\text { tenang }\end{array}$ & 69,35 & 81,25 & 11,9 \\
\hline $\begin{array}{l}\text { Menyelesaik } \\
\text { an soal tepat } \\
\text { waktu }\end{array}$ & 67,74 & 91,41 & 23,67 \\
\hline $\begin{array}{c}\text { Skor rata- } \\
\text { rata }\end{array}$ & 61,61 & 81,25 & 19,64 \\
\hline
\end{tabular}

Perbandingan skor Pemahaman Akuntansi per indikator untuk siklus I dan siklus II dapat disajikan pada grafik berikut ini:

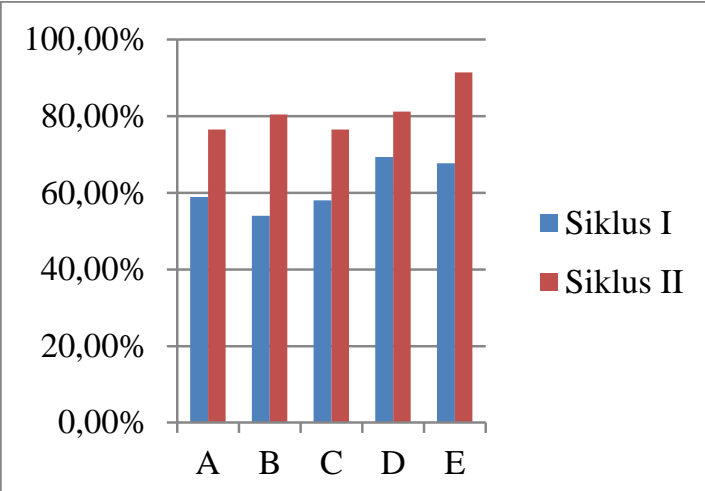

Gambar 1. Grafik Peningkatan Skor Pemahaman Akuntansi

Keterangan:

$\mathrm{A}=$ Memberikan interpretasi

$\mathrm{B}=$ Memberikan ide-ide dan pendapat

$\mathrm{C}=$ Memberikan contoh nyata dari suatu konsep

$\mathrm{D}=$ Mengerjakan soal dengan tenang

$\mathrm{E}=$ Menyelesaikan soal tepat waktu Sedangkan data mengenai perbandingan hasil tes siswa siklus I dan siklus II disajikan dalam tabel berikut:

Tabel 2. Perbandingan Persentase Hasil Tes Siswa

\begin{tabular}{|l|c|c|c|c|}
\hline \multirow{2}{*}{ Nilai } & \multicolumn{4}{|c|}{ Jumlah Siswa } \\
\cline { 2 - 5 } & \multicolumn{2}{|c|}{ Siklus I } & \multicolumn{2}{c|}{ Siklus II } \\
\cline { 2 - 5 } & $\begin{array}{c}\text { Pre- } \\
\text { test }\end{array}$ & $\begin{array}{c}\text { Post } \\
\text {-test }\end{array}$ & $\begin{array}{c}\text { Pre- } \\
\text { test }\end{array}$ & $\begin{array}{c}\text { Post } \\
\text {-test }\end{array}$ \\
\hline $\mathrm{n} \geq 75$ & 0 & 11 & 3 & 28 \\
\hline $\mathrm{n}<75$ & 32 & 20 & 29 & 4 \\
\hline $\begin{array}{l}\text { Jumlah } \\
\text { siswa }\end{array}$ & 32 & 31 & 32 & 32 \\
\hline $\begin{array}{l}\text { Jumlah } \\
\text { siswa } \\
\text { tuntas }\end{array}$ & 0 & 11 & 3 & 28 \\
\hline $\begin{array}{l}\text { Persentase } \\
\text { ketuntasan }\end{array}$ & $\begin{array}{c}0,00 \\
\%\end{array}$ & $\begin{array}{c}34,3 \\
8 \%\end{array}$ & $\begin{array}{c}9,38 \\
\%\end{array}$ & $\begin{array}{c}87,5 \\
0 \%\end{array}$ \\
\hline $\begin{array}{l}\text { Peningkat } \\
\text { an }\end{array}$ & $34,38 \%$ & $78,13 \%$ \\
\hline
\end{tabular}

Berdasarkan tabel di atas, perbandingan hasil tes siswa pada siklus I dan siklus II disajikan pada grafik berikut ini: 


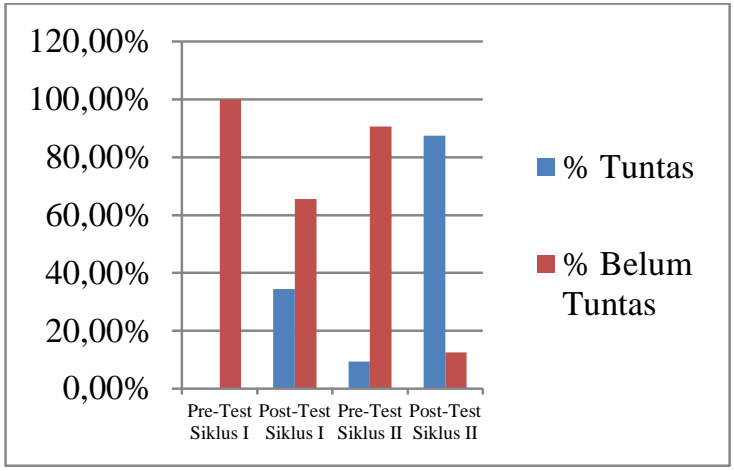

Gambar 2. Grafik Perbandingan Hasil Tes Siswa

Berdasarkan analisis data diketahui bahwa pada pre-test siklus I tidak ada siswa atau $0 \%$ yang tuntas KKM, setelah dilaksanakan kegiatan pembelajaran dengan Model Pembelajaran Kooperatif Tipe Jigsaw diketahui bahwa siswa yang tuntas menjadi 11 siswa atau 34,38\%. Berdasarkan analisis tersebut dapat diketahui terdapat kenaikan sebesar 34,38\% dari sebelum menggunakan Model Pembelajaran Kooperatif Tipe Jigsaw dengan setelah dilaksanakan pembelajaran dengan Model Pembelajaran Kooperatif Tipe Jigsaw. Berdasarkan analisis data juga diketahui bahwa pada pre-test siklus II terdapat 3 siswa atau 9,38\% yang tuntas KKM, setelah dilaksanakan kegiatan pembelajaran dengan Model Pembelajaran Kooperatif Tipe Jigsaw diketahui bahwa siswa yang tuntas KKM menjadi 28 siswa atau $87,50 \%$. Jadi terdapat kenaikan sebesar 78,13\%. Berdasarkan analisis tersebut dapat dilihat kenaikan dari pre-test siklus I ke post-est siklus I adalah sebesar 9,38\% dan kenaikan dari pre-test siklus II ke post-test siklus II adalah sebesar $53,13 \%$.

\section{SIMPULAN DAN SARAN Simpulan}

Berdasarkan hasil penelitian dan pembahasan pada bab IV dapat disimpulkan bahwa Model Pembelajaran Kooperatif Tipe Jigsaw dapat diterapkan dengan baik melalui tahapan: pembentukan kelompok asal, pembelajaran pada kelompok asal, pembentukan kelompok ahli, diskusi kelompok ahli, diskusi kelompok asal, diskusi kelas yang dipandu oleh guru, dan pemberian soal oleh guru. Implementasi Model Pembelajaran Kooperatif Tipe Jigsaw dapat meningkatkan Pemahaman Akuntansi siswa kelas X Akuntansi 2 SMK Negeri 7 Yogyakarta tahun ajaran 2013/2014 yang dibuktikan dengan adanya peningkatan persentase skor Pemahaman Akuntansi yang diperoleh melalui observasi terhadap proses dan hasil belajar siswa. Dari hasil observasi diperoleh skor pemahaman akuntansi secara klasikal pada siklus I sebesar $61,61 \%$ dan pada siklus II sebesar $81,25 \%$ yang berarti terjadi peningkatan sebesar 19,64\%. Berdasarkan analisis data diketahui kenaikan siswa yang tuntas KKM dari pre-test ke post-test siklus I adalah sebesar $34,38 \%$ yaitu dari pre-test siklus I sebesar $0 \%$ dan post-test siklus I sebesar 34,38\%, sedangkan kenaikan siswa yang tuntas KKM dari pre-test ke post-test siklus II adalah sebesar 78,13\% yaitu dari pre-test siklus II sebesar $9,38 \%$ dan posttest siklus II sebesar $87,50 \%$. Selain itu, diketahui terjadi kenaikan dari post-test siklus I ke post-test siklus II yaitu sebesar $17,94 \%$.

\section{Saran}

\section{Bagi Guru}

a. Guru dapat mencoba untuk menerapkan Model Pembelajaran Kooperatif Tipe Jigsaw pada kompetensi dasar yang lain yang diharapkan dapat meningkatkan pemahaman akuntansi dengan lebih menekankan pada pembelajaran yang berbasis student centered.

b. Dalam pelaksanaan pembelajaran, guru sebaiknya berperan sebagai fasilitator sehingga dapat memberikan kesempatan yang lebih luas kepada siswa untuk mengeksplorasi pengetahuan yang dipelajari melalui diskusi kelompok, 
presentasi, latihan soal, dan tanya jawab.

c. Indikator terendah pada akhir siklus yaitu indikator siswa mampu memberikan interpretasi dan siswa mampu memberikan contoh nyata dari suatu konsep dengan persentase sebesar 76,56\%. Hal ini dikarenakan siswa cenderung terpaku pada buku dan handout materi yang diberikan oleh guru. Guru seharusnya lebih mengarahkan dan membimbing siswa untuk memahami isi materi sehingga siswa mampu memberikan interpretasi dan contoh nyata dari konsep yang telah dipelajari.

\section{Bagi Siswa}

Siswa diharapkan dapat mengemukakan tanggapan, ide dan pendapatnya, serta mampu bekerjasama dengan baik dalam kelompok agar pembelajaran dapat dilaksanakan dari dua arah yaitu guru dan siswa.

\section{Bagi Peneliti Selanjutnya}

Untuk penelitian yang akan datang menggunakan model kooperatif tipe Jigsaw dapat menambah jumlah observer yang digunakan sehingga lebih cermat dalam observasi agar data yang diperoleh benar-benar mewakili kondisi siswa selama proses pembelajaran berlangsung.

\section{DAFTAR PUSTAKA}

Agus Suprijono. (2012). Cooperative Learning Teori \& Aplikasi PAIKEM. Yogyakarta: Pustaka Pelajar.

Anita Lie. (2008). Cooperative Learning: Mempraktikkan Cooperative Learning di Ruang-Ruang Kelas. Jakarta : Grasindo.

Isjoni dan Mohd. Arif Ismail. (2008). Model-Model Pembelajaran Mutakhir. Yogyakarta: Pustaka Pelajar.
Miftahul Huda. (2012). Cooperatif Learning. Yogyakarta: Pustaka Pelajar.

Moh. Sholeh Hamid. (2011). Standar Mutu Penilaian dalam Kelas. Yogyakarta: Diva Press.

Muhibbin Syah. (2010). Psikologi Pendidikan dengan Pendekatan Baru. Bandung: PT Remaja Rosda Karya.

Mulyasa. (2009). Praktik Penelitian Tindakan Kelas. Bandung : PT Remaja Rosda Karya.

\section{(2010). Kurikulum Tingkat} Satuan Pendidikan. Bandung: PT Remaja Rosdakarya.

Nana Sudjana. (2009). Penilaian Proses dan Hasil Pembelajaran. Jakarta: Bumi Aksara.

Rochiati Wiriaatmadja. (2006). Metode Penelitian Tindakan Kelas untuk Meningkatkan Kinerja Guru dan Dosen. Bandung: Remaja Rosdakarya.

Rusman. (2011). Model-Model Pembelajaran Mengembangkan Profesionalisme Guru. Jakarta: PT Raja Grafindo Persada

Slavin.E. Robert. (2005). Cooperative Learning. Teori, Riset, dan Praktik. Bandung: Nusa Media.

Sugiyono. (2009). Metode Penelitian Pendidikan. Bandung: Alfabeta.

Penelitian. Bandung. Alfabeta.

Wijaya Kusumah dan Dedi Dwitagama. (2011). Mengenal Penelitian Tindakan Kelas. Jakarta: PT Indeks. 
Jurnal Pendidikan Akuntansi Indonesia, Vol. XII, No. 1, Tahun 2014

Suhartini \& Sukanti

$1-11$

Zainal Arifin. (2012). Evaluasi Pembelajaran. Bandung: PT Remaja Rosdakarya.

Zainal Aqib, dkk. (2008). Penelitian Tindakan Kelas. Bandung: CV Yrama Widya. 